[CONTRIBUTIONS FROM THE HAVEMEYER LABORATORIAS OF COLUMBIA UNIVERSTTY, NO. I20.]

\title{
THE OSAZONE TEST FOR GLUCOSE AND FRUCTOSE AS INFLUENCED BY DILUTION AND BY THE PRESENCE OF OTHER SUGARS.
}

\author{
BY H. C. SHERMAN AND R. H. WILIIAMS.
}

Received February 26, 1906.

MAQUENNE ${ }^{1}$ found that the reducing sugars when treated in a uniform way with phenylhydrazine showed considerable differences both in the yield of osazone and in the time required for the appearance of the osazone precipitate. Mulliken ${ }^{2}$ has studied these differences in rapidity of osazone formation and makes use of them to an important extent in his scheme for the identification of pure sugars. According to Mulliken, o. I gram sugar, 0.2 gram pure phenylhydrazine hydrochloride, 0.3 gram sodium acetate and 2 cc. water are mixed in a small test-tube, corked loosely to prevent evaporation and heated in boiling water. If the tube is occasionally shaken without removing it from the boiling water, the osazone precipitate usually separates out quite suddenly so that duplicate experiments usually give results that agree within half a minute. Under these conditions the time required for the appearance of the osazone in the hot solution is given by Mulliken as follows: Fructose, two minutes; sorbinose, three and one-half minutes; glucose, four to five minutes; xylose, seven minutes; rhamnose, nine minutes; arabinose, ten minutes; galactose, fifteen to nineteen minutes. Sucrose, after about thirty minutes' heating, is sufficiently hydrolyzed to yield a precipitate of osazone. Maltose and lactose give no precipitate in the hot solution even when the heating is continued for two hours.

In our experiments we have followed closely the conditions adopted by Mulliken except that, for greater convenience of manipulation, twice the quantities were used throughout. Having confirmed the results above given for glucose, fructose, sucrose, maltose and lactose at the standard dilution, we determined the times required for the osazone precipitation with smaller amounts of glucose or fructose in pure solution and also when different

1 Compt. rend. II2, 799.

2 "Identification of Pure Organic Compounds." 
amounts of other sugars were present at the same time. Every test was carried out as has been described, using 0.4 gram phenylhydrazine hydrochloride, 0.6 gram sodium acetate, and $4 \mathrm{cc}$. water, so that the only variable factor was the amount of sugar or sugars present. The tabular statements which follow show the time required for the appearance of an osazone precipitate in each case.

Pure Solutions of Glucose, Fructose, InVert Sugar, and Sucrose.

$\begin{array}{ccc}\begin{array}{c}\text { Weight of } \\ \text { sugar taken. } \\ \text { Gram. }\end{array} & \begin{array}{c}\text { Glucose. } \\ \text { Minutes. }\end{array} & \begin{array}{c}\text { Fructose. } \\ \text { Minutes. }\end{array} \\ 0.2 & 4-5 & \mathrm{I} \frac{1}{2}-\frac{1}{2} \\ 0.1 & 5 & \mathrm{I}^{\frac{3}{4}}-2 \\ 0.05 & 6 \frac{1}{2} & 2 \frac{1}{2} \\ 0.01 & \mathrm{I} 7 & 5 \frac{1}{2} \\ 0.005 & 34 & 10 \\ 0.0025 & 65 & 17\end{array}$

\begin{tabular}{|c|c|}
\hline $\begin{array}{l}\text { Invert sugar. } \\
\text { Minutes. }\end{array}$ & $\begin{array}{l}\text { Sucrose. } \\
\text { Minutes. }\end{array}$ \\
\hline$I \frac{1}{2}-I \frac{2}{3}$ & $3 I$ \\
\hline 2 & 35 \\
\hline 3 & 78 \\
\hline $6-6 \frac{1}{2}$ & No ppt \\
\hline
\end{tabular}

With less than 0.005 gram glucose or 0.0025 gram fructose, the amount of osazone separating in the hot solution was small and the time of its appearance doubtful.

Influence of Maltose on Glucose.

Weight of
glucose.
Gram.
0.01
0.02

\begin{tabular}{|c|c|c|c|c|}
\hline \multicolumn{4}{|c|}{ Weight of maltose. } & $\begin{array}{c}\text { In absence } \\
\text { of } \\
\text { maltose. }\end{array}$ \\
\hline $\begin{array}{l}0.2 \text { gram. } \\
\text { No ppt. } \\
26-28 \mathrm{~min}\end{array}$ & $\begin{array}{l}\text { O. } \mathrm{gram} . \\
40 \mathrm{~min} .\end{array}$ & $\begin{array}{c}0.05 \text { gram. } \\
30 \mathrm{~min} .\end{array}$ & $\begin{array}{l}0.01 \text { gram. } \\
22 \text { min. }\end{array}$ & $\begin{array}{l}\text { maltose. } \\
\text { I } 7 \mathrm{~min} . \\
\text { I } 2-13 \mathrm{~min} .\end{array}$ \\
\hline
\end{tabular}

INFLUENCE OF LACTOSE ON GLUCOSE.

\begin{tabular}{|c|c|c|c|c|c|}
\hline \multirow{2}{*}{$\begin{array}{l}\text { Weight of } \\
\text { glucose. } \\
\text { Gram. }\end{array}$} & \multicolumn{4}{|c|}{ Weight of lactose. } & \multirow{2}{*}{$\begin{array}{c}\text { In absence } \\
\text { of } \\
\text { lactose. }\end{array}$} \\
\hline & 0.2 gram. & 0.1 gran & 0.05 gram. & o.or gram. & \\
\hline $0.0 I$ & No ppt. & $50 \mathrm{~min}$. & $32 \mathrm{~min}$. & $25 \mathrm{~min}$. & $17 \mathrm{mis}$ \\
\hline 0.02 & $45-48 \mathrm{~min}$. & & & & $12-131$ \\
\hline
\end{tabular}

It is evident that both maltose and lactose interfere seriously with the formation and precipitation of glucosazone and that the influence of lactose is greater than that of maltose. Thus a mixture of o.or gram glucose and o.I gram lactose required ten minutes' longer heating than a parallel mixture with 0.1 gram maltose, and when the quantities of glucose, lactose, and maltose are doubled (the amounts of reagents and the volume of the solution remaining the same) the lactose mixture required twenty minutes' longer heating than the maltose mixture. 
INFLUENCE OF SUCROSE ON GLUCOSE.

Weight of glucose.

Gram.

0.005

0.01

0.2

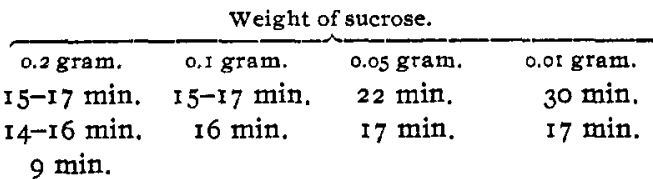

In absence

sucrose.

33-39 min.

$17 \mathrm{~min}$.

I 2-I 3 min

INFLUENCE OF RAFFINOSE ON GLUCOSA.

Weight of
glucose.
Gram.
0.005

Weight of fructose. Gram. Weight of raffinose,

$0.2 \mathrm{gram}$. $0.1 \mathrm{gram}$. $0.05 \mathrm{gram}, 0.01 \mathrm{gram}$.

27-30 min. 33-37 min. 36-38 min. 37-39 min. 33-39 min.

INFLUENCE OF MALTOSE ON FRUCTOSE.

O.OI

Weight of fructose.

Gram.

\begin{tabular}{|c|c|c|c|}
\hline & Weig & of maltose. & \\
\hline $\begin{array}{l}0.2 \mathrm{gram} \text {. } \\
7-8 \mathrm{~min} \text {. }\end{array}$ & $\begin{array}{l}0.1 \text { gram. } \\
5 \frac{1}{2}-6 \text { min. }\end{array}$ & $\begin{array}{c}0.05 \text { gram. } \\
5 \frac{1}{2}-5 \frac{3}{4} \mathrm{~min} .\end{array}$ & $\begin{array}{c}0.01 \text { gram. } \\
5 \frac{1}{2} \mathrm{~min} .\end{array}$ \\
\hline
\end{tabular}

INFLUENCE OF LACTOSE ON Fructose.

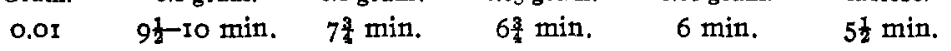

Comparing these results with the corresponding figures for glucose it will be seen that the interference of maltose and lactose is less marked with fructose than with glucose. In both cases, however, the appearance of the osazone precipitate is retarded distinctly by maltose and to a greater extent by lactose.

Weight of
fructose.
Gram.
0.005

INFLUENCE OF SUCROSE ON FrUCTOSE.

\begin{tabular}{|c|c|c|c|}
\hline \multicolumn{4}{|c|}{ Weight of sucrose. } \\
\hline $\begin{array}{l}0.2 \mathrm{gram} . \\
8 \frac{1}{2} \mathrm{~min} .\end{array}$ & $\begin{array}{l}\text { o.r gram. } \\
83 \text { min. }\end{array}$ & $\begin{array}{l}0.05 \text { gram. } \\
9 \frac{1}{3} \text { min. }\end{array}$ & $\begin{array}{l}\text { o.or gram. } \\
9 \frac{1}{4} \text { min. }\end{array}$ \\
\hline
\end{tabular}

SUMMARY OF RESULTS.

In pure glucose solutions tested at constant volume with fixed amounts of phenylhydrazine hydrochloride and sodium acetate the time required for the precipitation of osazone varies with the amount of glucose present and is nearly constant for any given dilution.

Pure solutions of fructose show similar variations with concentration but always yield a precipitate of osazone in about onethird the time required by the same amount of glucose.

From invert sugar solutions the osazone precipitates almost as rapidly as from fructose solutions of the same concentration.

In solutions containing only about 0 . I per cent. of glucose the time required for the precipitation of osazone is shortened con- 
siderably by the presence of I per cent. or more of sucrose; only slightly by the presence of 5 per cent. of raffinose.

Sucrose also accelerates the osazone precipitation in dilute solutions of fructose, but as these react much more rapidly than the corresponding glucose solutions, the effect of the sucrose is scarcely noticeable.

Maltose retards the precipitation of glucosazone, interfering much more seriously in the case of glucose than in the case of fructose.

Lactose interferes with the glucosazone test in a similar manner and to a greater degree than maltose.

The bearing of these results upon the analytical application of the osazone reaction is too evident to require detailed discussion.

We plan to continue this work by studying the influence of maltose, lactose, and sucrose upon the yield and physical properties of glucosazone and later to extend the investigation to other substances and to the corresponding reaction with derivatives of phenylhydrazine. QVANTITATIVE LABORATORY,
Februaty 6, Igo5.

\section{THE SAMPLING OF COAL AND CLASSIFICATION OF ANALYTICAL DATA.}

By A. BEMENT.

Received December 20, 1905.

IF $A$ history of the sample of coal were given with the results of the analysis, it would be of great service, and if this becomes standard practice, one would be able to arrive at a more definite conclusion as to what an analysis represented. It is very often the case that the chemist analyzes a sample stated to be representative of a certain mine, seam, locality or kind of coal, and yet knows nothing regarding its selection; the result is, that he may present a report that is erroneous, because the sample may have been a picked one, better than is possible with the average product. Or, on the other hand, it may be an inferior one, with the result that in each case the chemist's work does not appear to the best advantage. A comparison of various published analyses of what is presumably the same coal, will show a most confusing series of results that cannot be explained by any assumption that the analytical methods differ. Many of the composi- 